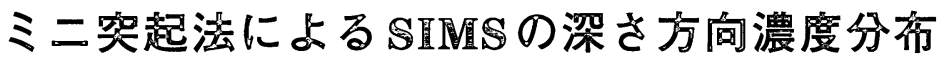 測定精度の向上
}

\author{
住谷弘幸・武藤勝美・田村一二三・関＼cjkstart節子* \\ 日立計測エンジニアリング（株） 312 茨城県ひたちなか市市毛 882 \\ *拓殖大学 工学部 193 東京都八王子市舘町 815-1 \\ （1995年 9 月 14 日受付：1995年12月27日掲載決定）
}

\section{Improvements of the Accuracy of Depth Profiling in Secondary Ion Mass Spectrometry (SIMS) by using a Mini-Projection Technique}

\author{
Hiroyuki Sumiya, Katsumi Muto, Hifumi Tamura and Setsuko SeKi* \\ Hitachi Instruments Engineering Co. Ltd., Hitachinakashi, Ibaraki 312 \\ *Faculty of Engineering, Takushoku University, 815-1 Tatemachi, Hachioji, Tokyo 193
}

(Received September 14, 1995 : Accepted December 27, 1995)

\begin{abstract}
A mini-projection technique to be applied to the practical depth profiling in secondary ion mass spectrometry (SIMS) has been developed. This new method is combination of a sample pretreatment and a high acceptance (sensitive) technique for secondary ion optics. The sample pretreatment makes it possible to removes the interfering secondary ions that originate at the periphery of the ion beam etched crater so that high depth resolution can be attained. In this high acceptance technique the least confusion circle (crossover point) of the secondary ion beam is placed at the entrance slit of a double-focussing mass spectrometer so as to obtain high sensitivity in depth profile measurements. To evaluate the detection limit and depth resolution of the mini-projection method, $\alpha \mathrm{Si}: \mathrm{H}$ thin films deposited on Si wafer and on B-implanted Si wafer were measured in the depth analysis mode. As result, the depth resolution of the $\mathrm{O}$ and $\mathrm{C}$ atoms included in the $\alpha \mathrm{Si}$ thin films increased as indicated by the steepness of the concentration gradient ( $\Delta Y$ was reduced by one-thirds compared to the value obtained by the conventional method). The detection limit for $\mathrm{B}$ in this proposed method is also reduced to about $40 \%$ of that in the conventional method.
\end{abstract}

\section{1.はじめに}

2 次イオン質量分析法 (SIMS) は多くの問題点を包含 しているにもかかわらず, 微量元素の深さ方向濃度分布 の測定においてユニークな特徵があり, 分析法としての 位置を確立しつつあるといえる。特に半導体材料におけ る微量不純物分布の測定分野においては，他の類似分析 法の追従を許さないSIMS の独壇場といっても過言では ない。

一方，深さ方向濃度分布の深さ分解能については多く の装置的改良がなされてきたが，まだ十分に満足できる 状況になく, さらに定量精度およびデー夕解析法などの 分析ソフトを含めた総合的な観点からの改善が望まれ
る。樑さ方向分布測定における深さ方向分解能劣化の要 因としてよく知られているように, 主につぎの点が指摘 できる。

1) ノックオン効果

2) エッチングクレータ周辺部からの妨害イオン*の 混入

3) 試料周辺部污染によるメモリー効果

4) 質量スペクトル干渉

これらのうち，1)はSIMSの本質的な問題点であり回避 は困難であるが, 1 次イオンのエネルギーを最適化する ことで軽隇できる11。3) は周辺污染部を分析対象元素そ

* 深さの異なったエッチングクレータ周辺部に起源をもち深 さ方向分解能に悪影響を与えるイオン。 
の他質量干渉のない無害の物質で試料周辺部を被覆する ことにより回避できる2)。4) は高質量分解能化および干 渉のない同位体を選択することにより回避が可能であ る。2) は上述の 1)，3），および4）に比較して最も大き な妨害因子であり, 従来 SIMS の深さ方向分析精度の向 上は主にハードの観点より2) との戦いであったといえ る。2)の回避法として主としてエレクトロニックアパー チャリング法や制限視野法が開発され，飛躍的に深さ分 解能が向上し，実用されているが，高精度を要求される 深さ方向濃度分布の測定には必ずしも十分とはいえな い。これらの二つの技法はいずれも分析領域周辺部から の妨害イオンを信号と一緒にいったん 2 次イオン光学系

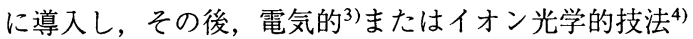
により，妨害イオンを除去する方法を採用している。そ のため 1 次イオンビーム分布における裾部の広がりおよ び2次イオン光学系の収差により混入する妨害イオンが 十分に除去できず，信号中に混入し，高精度分析には問 題を残しているといえる。

このような観点から, 本研究では, 妨害イオンをその 発生源で除去し, 真の信号のみを2次イオン光学系に導 きかつ効率よく2 次イオンを検出する新しい試料前処理
法および高効率 2 次イオン光学系の利用法を併用したミ 二突起法について評価したので，実験結果を報告する。

\section{2. 試料前処理法}

はじめに試料前処理法を利用してエッチングクレータ 周辺部からの妨害イオンをその源で除去する新しいミニ 突起作製法の詳細について述べる。本技法の基本的な考 え方は深さ方向濃度分布測定において分析対象領域のみ を残して周辺部を測定対象深さ以上の深さまで除去した ミ二突起を作製し, 測定は突起表面から梁さ方向に行う ことにある。本技法の狙いは，上述のように妨害イオン をその源で除去し, 深さ方向濃度分布の高精度測定を行 うことにある。

ミ二突起作製工程のフローチャートおよび各加工工程 に対応した試料の加工形状を Fig. 1 に示す。図に示し たように，まず試料の所望の場所に，所望の寸法のマス クを取り付ける。具体的にはあらかじめ種々の形状のマ スクを作製しておき，分析目的に合ったマスクを選択し て利用する。膜生成時におけるマスクのへリ（穴端部） の影響を考慮してマスクは, 厚さ $300 \mu \mathrm{m}$ 以下の薄板で 作製した。また材質としては質量干渉が比較的少ないと

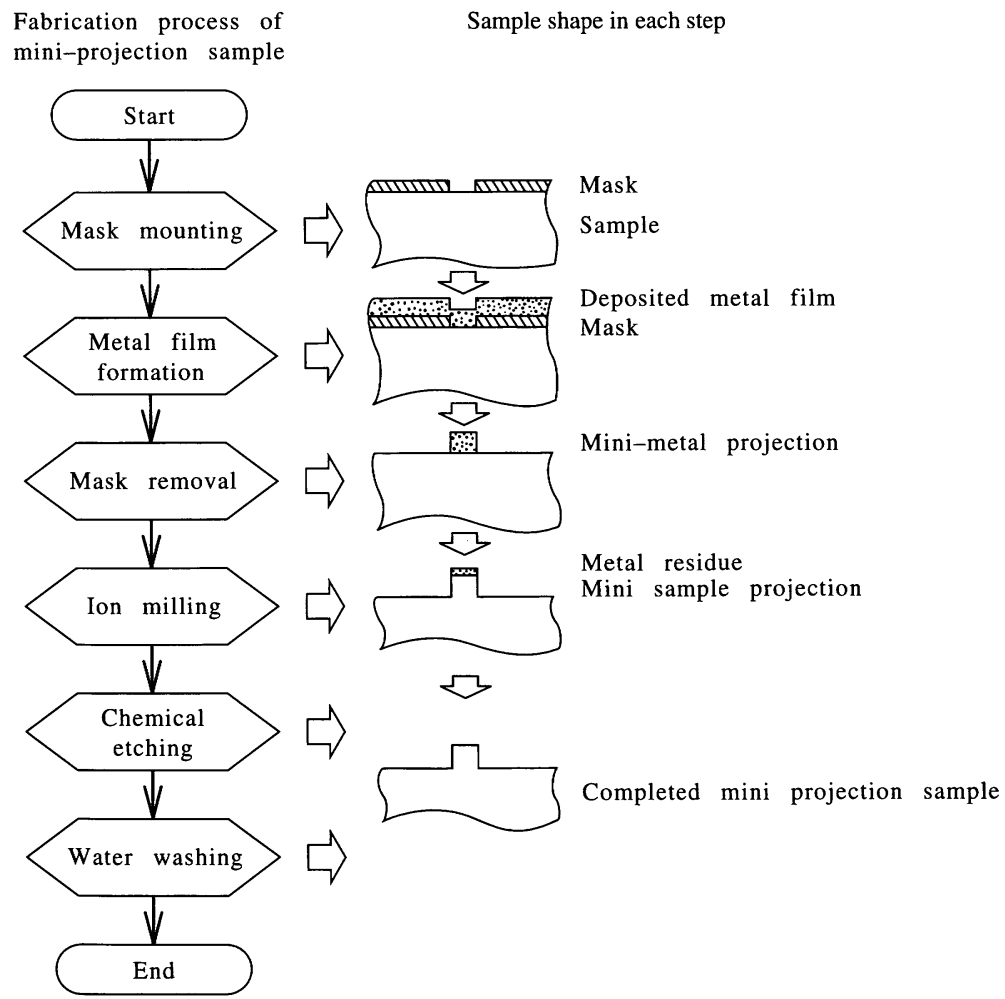

Fig. 1 Fabrication process for mini-projection sample and sample shape in each process step. 


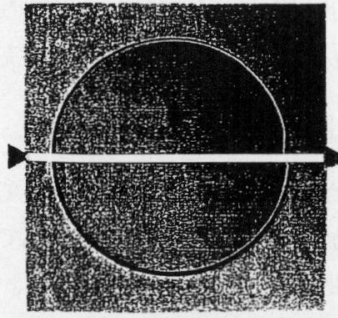

(a)

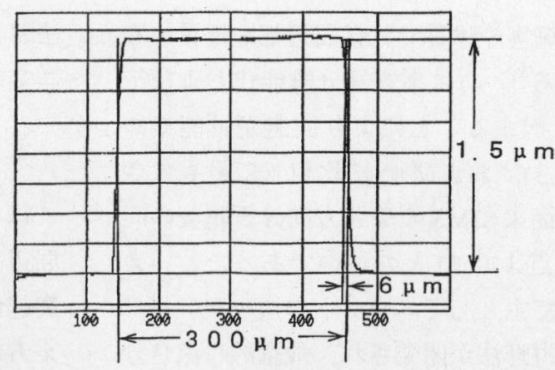

(b)

Fig. 2 Plane photograph of mini-projection (a) and the projection profile (b) measured along the arrow in (a).

考えられる高質量数をもつ Mo を採用したが，一般には 試料污染も考虑に入れてマスク材料を選択する必要があ る。マスク装着後, 測定面保護を目的に膜生成を行う が, この場合，膜材質の選択には，測定元素の質量干渉 を十分に考慮して決める必要がある。膜厚は測定対象の 深さとスパッタレイトを考虑して決定する。つぎにイオ ンミーリング法により加工を施し，わずかに金属膜を残 した状態でミニ突起を形成する。最後に，化学エッチン グ法により，付着膜のみを選択的に除去し，さらに水洗 により表面付着物を除去する。以上の工程により，ミニ 突起作製は完了するが，終りの二つの工程すなわちイオ ンミーリング後に残る金属膜の除去および水洗は省略 し，目的によっては，金属膜を一部残し，キャッピング 法**として 1 次イオン注入深さ近傍の薄い表面層の高精 度分析に利用することもできる。

つぎにミニ突起作製例を示す。種々の材料についてミ 二突起を作製したが，ここでは $\mathrm{Si}$ ウェハにミニ突起を 形成させた例を示す。穴加工は数百 $\mu \mathrm{m}$ 径以上の大きい ものに対しては超音波加工を，またこれ以下の穴に対し てはFIB (Focused Ion Beam) 加工法を採用した。金属 膜は材質として高純度 $\mathrm{Al}$ を採用し, 膜厚として $1.5 \mu \mathrm{m}$ におさえた。イオンミーリングは日立E-3200形フラッ トミーリング装置を利用して行った。 $\mathrm{Al}$ 膜は $\mathrm{NaOH}$ 溶 液による化学エッチング法により, 除去し, さらに蒸留 水洗浄を施した。Fig. 2 (a) および (b) はそれぞれ上述 の条件で作製したミ二突起を上部から見た写真 (a) とミ 二突起の断面形状を表面形状測定器 (Dektak 3030) で測 定した結果 (b)を示す。(b)の突起形状は (a) に示した矢 印方向に沿って測定した。(b)より，突起はマスクサイ ズによく合った $300 \mu \mathrm{m}$ の直径をもち, 周辺部に約 $6 \mu \mathrm{m}$ 程度の裾広がりが観察される。この裾広がりは突起径の $300 \mu \mathrm{m}$ に対して $2 \%$ 程度であり, 深さ方向濃度分布の測

**あらかじめ試料と同種の膜を注入飛程の 2 倍以上の厚さに 付着させ，1 次イオン種注入効果を回避する技法。
定精度においては無視できると考えられる。

以上は，マスクサイズとして比較的大きい $300 \mu \mathrm{m}$ 径 の例を示したが, FIB 技術などの利用により, 数 $\mu \mathrm{m}$ 径 程度のマスク作製も可能である。また必要に応じて，さ まざまな形状のマスクを作製し，各種分析ニーズに応え ることも可能である。

\section{2 次イオン光学系におけるアクセプタンス の改善}

前章で述べたミニ突起の採用により，周辺部からの妨 害 2 次イオンがその源でほぼ完全除去でき, 2 次イオン 光学系に導入されるイオンはほとんどすべて真の情報を もっているといえる。そのため，2次イオン光学系におけ る2次イオンの高効率検出が高感度化の重要課題となる。

このような観点より, 2 次イオンの質量分析計への導 人効率向上のための新しい 2 次イオン引出レンズの利用 法について実験した。Fig. 3 (a)，(b) および (c) はそ れぞれ実験に利用した日立IMA3000形イオンマイクロ アナライザの 2 次イオン光学系の構成, 従来の引出レン ズ利用法および今回採用した新しいレンズ利用法を示 す。質量分析計としてはエネルギーおよび方向収束を可 能にする二重収束形質量分析計を採用した。

従来法では，常にエッチングクレータ周辺部からの妨 害イオンが2次イオン引出レンズ系に混入しており，質量 分析計に入る前に妨害イオンを除去する必要がある。(b) は，従来法の説明図であり，周辺部から混入する妨害イ オンの除去を目的とした引出レンズの利用法 (制限視野 法)を示す。この方法では, 試料上における2次イオンの エミッションパターンを2次イオン引出レンズにより, 質 量分析計の入射スリットのところに拡大, 結像させ，入 射スリットにより，周辺部からの妨害イオンを除去し信 号のみを質量分析計に導入するようにしている。この場 合，像質は主に引出レンズの球面収差と色収差により左 右され，妨害イオンの混入は避けられず，その量をでき 
(a) Entire secondary ion optics

(b) Conventional secondary ion extraction optics

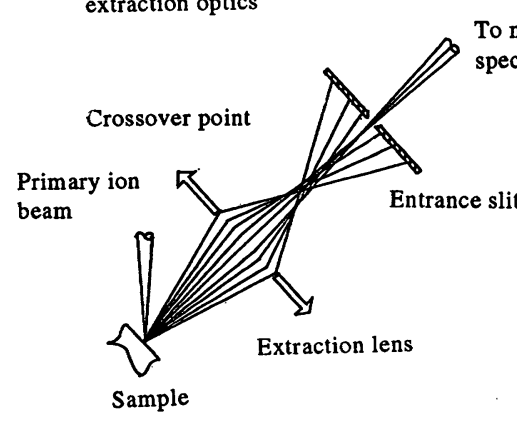

Double focussing

mass spectrometer

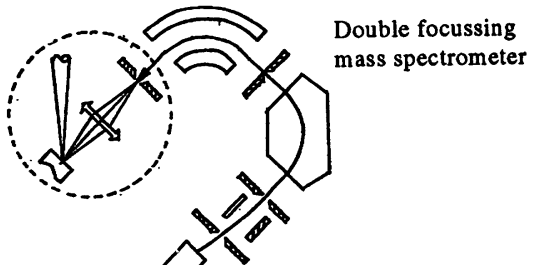

(c) Proposed secondary ion extraction optics

Fig. 3 Secondary ion extraction systems in conventional and proposed technique.

るだけ減少させる目的で入射スリットを細く絞って対処 している。その結果として信号分も含めてかなりのイオ ン量がカットされ, 感度低下を招いていた。さらに上述 の収差により，入射スリット中を妨害イオンが通過し， 深さ方向濃度分布に打ける深さ分解能が低下する。

ここに提案するミニ突起法は, 従来法との本質的な差 として，妨害イオンをその発生源で除去してしまうこと に特徵がある。この特徵を生かすために, 引出レンズは Fig. 3 (c) に示したように, 質量分析計の入射スリット の位置に2 次イオンビームのクロスオーバ点 (最小錯乱 円）がくるように調整する。これにより2次イオンのエ ネルギー差抢よび方向の異なったイオンも効率よく入射 スリットに導入される。一方，二重収束形質量分析計 は, 本来エネルギー収束 (エネルギーが多少異なっても 一点に収束する) と方向収束 (入射方向が多少異なって も一点に収束する) 特性をもっており，その結果，入射 スリットに導入される 2 次イオンはほとんどすべて有効 に利用され，感度向上が達成される。クロスオーバ点を 入射スリット位置に合わせる調整は先に開発した全イオ ンモニター法5)を利用して行い，モニター電流が最大值 をもつように設定する。クロスオーバの寸法は試料上の 走査領域の広さに応じて増加する。一方，利用した日立 IMA-3000形イオンマイクロアナライザの入射スリット 開放時の実効的なアクセプタンスすなわち2次イオン光 学系で検出しうる試料上の 2 次イオンのエミッション領 域は，ほほ $400 \mu \mathrm{m} \times 400 \mu \mathrm{m}$ である。現在，深さ方向分 析における測定領域は大部分が数十 $\mu \mathrm{m}$ から数百 $\mu \mathrm{m}$ で
あり，上述のアクセプタンス以下であり，ほほ2次イオ ン引出し領域の $100 \%$ 近くが有効に利用できるといえ る。ただし，特に高分解能が要求される場合，入射ス リット位置における2次イオンビーム径は質量分解能と 反比例関係(6)にあり, 要求される質量分解能に応じて入 射スリットの寸法を調整する必要がある。

\section{4. 結果と考察}

ここでは，前章で述べたミニ突起と2次イオン引出レ ンズを高アクセプタンス条件で利用する二つの技法を組 合せたミニ突起法を適用して, 実用的な観点より深さ方 向濃度分布測定モードに扔ける深さ方向分解能および高 感度化の評価を試みたので，その結果を述べる。

\section{$4.1 \mathrm{Si}$ 単結晶上アモルファス, $\alpha \mathrm{Si}: \mathrm{H}$ 膜に おける深さ方向分解能評価}

実験に使用した試料は $\mathrm{Si}$ 単結晶ウェハ上に, Si クラ ス夕を用いて $10^{-2} \mathrm{~Pa}$ の水素ガス中で作製した。 $\alpha \mathrm{Si}: \mathrm{H}$ 膜の厚さは $100 \mathrm{~nm}$ である。測定に際しての試料前処理 は，まず厚さ $300 \mu \mathrm{m}$ の Mo 板に $300 \mu \mathrm{m}$ 径の 6 個の穴を あけたマスクを利用し，金属膜として $\mathrm{Al}$ 膜を約 $1 \mu \mathrm{m}$ 蒸 着した。つぎにマスクを外しアルゴンイオンビームエッ チングを施し, 最後に $\mathrm{Al}$ 膜残滓を $\mathrm{NaOH}$ 溶液で溶解除 去し，蒸留水洗浄を施しミ二突起試料とした。

測定は，まずミ二突起のみの効果を評価することを目 的として，ミ二突起試料と末処理試料に対して同一測定 条件で測定した。この実験では，ミ二突起のみの効果を 評価する目的で, 2次イオン光学系の高アクセプタンス 
化は行わなかった。測定条件の詳細を Table 1 に示 す。Fig. 4 は両試料に対してマトリックスの Si, 不純 物のOおよびCの深さ方向濃度分布の測定結果を示す。 図中 (a) および (b) はそれぞれ未処理試料, ミ二突起試 料における生デー夕を示した。(c) は比較のため (a) およ び(b)の結果を同一グラフ上に表わしたものである。検 出元素の C および $\mathrm{O}$ は $\alpha \mathrm{Si}: \mathrm{H}$ の成膜中に混入した元 素である。つぎにこれらの実験デー夕をもとに従来法と ミニ突起法における深さ分解能 (濃度の急峻性) の定量 評価を試みた。Fig. 5 に深さ方向分解能の評価法を示 す。図において, 深さ分解能は物質 $\mathrm{A}$ および物質 B が 層構造を有している系を想定し, まず両者の境界層にお ける A または B の濃度勾配を実測する。つきに A また は B 関連イオン強度がそれらの飽和値の $16 \%$ から $84 \%$ の間に挟まれる厚さ（または深さ）を深さ方向分解能,

Table 1 Analytical conditions in depth profile measurement of $\alpha \mathrm{Si}$ : $\mathrm{H}$ thin film deposited on $\mathrm{Si}$ wafer and $\mathrm{B}$ inplanted $\mathrm{Si}$ wafer.

\begin{tabular}{lc}
\hline \multicolumn{1}{c}{ Item } & Analytical conditions \\
\hline Primary ion species & $\mathrm{Cs}^{+}$ \\
Primary ion beam energy $(\mathrm{keV})$ & 10 \\
Primary ion beam current $(\mathrm{nA})$ & 100 \\
Primary ion beam diameter $(\mu \mathrm{m})$ & 60 \\
Scanning area $\left(\mu \mathrm{m}^{\square}\right)$ & 500 \\
Signal pick-up area & 90 \\
Entrance slit size $\left(\mu \mathrm{m}^{\square}\right)$ & 50 \\
Ultimate pressure $(\mathrm{Pa})$ & $5 \times 10^{-8}$ \\
Secondary ion species & ${ }^{28} \mathrm{Si}^{-},{ }^{16} \mathrm{O}^{-},{ }^{12} \mathrm{C}^{-}$ \\
Height of mini-projection $(\mathrm{nm})$ & $500 \sim 1500$ \\
\hline
\end{tabular}

$\Delta Y$ と定義して定量評価を行った。Table 2 は $\alpha \mathrm{Si} ： \mathrm{H}$ 膜中に含有するCおよび $\mathrm{C} に$ 対して $\Delta Y$ を求めた結果を 示す。表より，ミニ突起を採用した場合のCおよびOの $\Delta Y$ 值は従来法に比較して約 $1 / 3$ に減少しており, 顕著 な改善が認められる。感度に関しては向上が認められな いが，これは前記したように，本実験ではミニ突起のみ の効果を区別して評価することを目的とし2次イオン引 出レンズ条件を従来法に合わせて測定したことによると いえる。

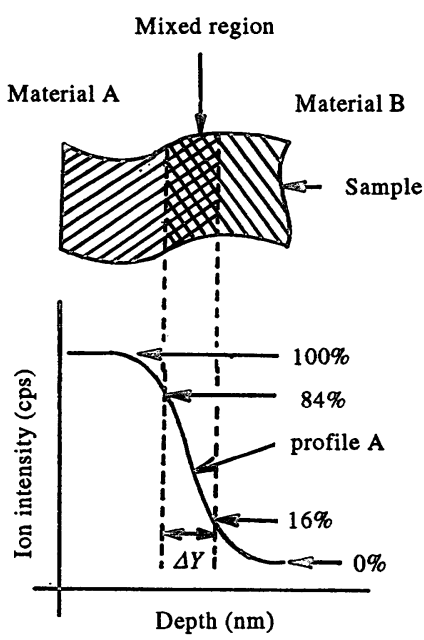

Fig. 5 Definition of depth resolution $(\Delta Y)$ in depth profile measurements.
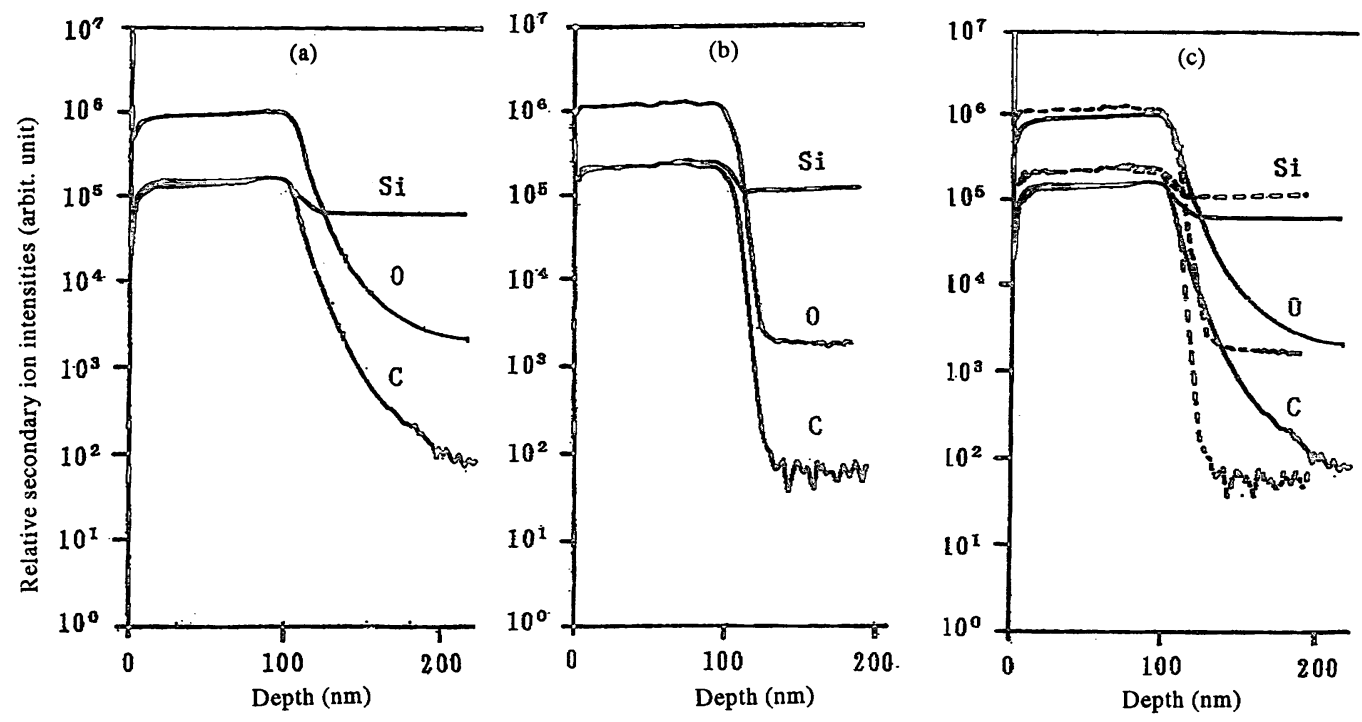

Fig. 4 Depth profiles measured by conventional technique and new mini-projection technique. (a) Conventional, (b) proposed, (c) comparison of (a) and (b). 
Table 2 Evaluation of depth resolution, $\Delta Y$ in depth analysis for $\mathrm{Si}-\alpha \mathrm{Si}: \mathrm{H}$ samples with and without treatment.

\begin{tabular}{ccc}
\hline Element & $\begin{array}{c}\text { Depth resolution in } \\
\text { untreated sample, } \Delta Y \\
(\mathrm{~nm})\end{array}$ & $\begin{array}{c}\text { Depth } \\
\text { mini-projection sample, } \Delta Y \\
(\mathrm{~nm})\end{array}$ \\
\hline $\mathrm{C}$ & 3.7 & 1.1 \\
$\mathrm{O}$ & 3.4 & 1.0 \\
\hline
\end{tabular}

\section{$4.2 \mathrm{~B}$ 注入 $\mathrm{Si}$ 単結晶ウェハ試料における B の} 深さ方向濃度分布の測定

ここではミニ突起と 2 次イオン光学系の高アクセプタ ンス化技法との相乗効果を評価した結果を述べる。

試料として，エネルギーおよび濃度をそれぞれ $30 \mathrm{keV}$ および $10^{14}$ atoms $/ \mathrm{cm}^{2}$ の条件でイオン注入したSi ウェハ を用いた。測定は, 高アクセプタンス化を指向して2次イ オン引出レンズは入射スリット位置に2次イオンビームの クロスオーバ点をもってくるように調整した（Fig. 3 (c) 参照)。

Fig. 6 (a), (b) および (c) はそれぞれ従来法の測定 結果の典型例高アクセプタンス技法を併用したミニ突起 法による測定結果の典型例および両者の比較結果を示
す。Fig. 6 より, ミニ突起法と高アクセプタンス法を 組合せた技法では, 深さ方向分解能および感度とも著 しく向上していることがわかる。計測した数値リスト (省略)より，Bイオン強度の深さ分解能， $\Delta Y$ および従 来法とのイオン強度比 (新技法による B イオン強度/従 来法による B イオン強度) を定量的に評価した結果を Table 3 に示す。従来法による測定データから求めた 標準偏差 (standard deviation, $\Delta R_{p}$ ) は $43.5 \mathrm{~nm}$ であり, 理論值7)と比較して $16 \%$ 程度大きい值をもつが, 本技法 の結果では, $38.2 \mathrm{~nm}$ が得られており理論値に対して $2 \%$ 以下の精度で良く合っていることがわかる。この結果 は, エレクトニックアパーチャリング法と制限視野法を 併用する従来法では，妨害イオンが十分に除去されてい ないことを示している。妨害イオンの起源としては, エッチングクレータ周辺部で発生し, 2 次イオン光学系 に直接混入するイオンとエッチングにより生成されるク レータ周辺部からスパッタされる粒子が中央部の信号検 出領域に付着し, 再度イオンとして放出し, 2次イオン 光学系に混入するイオンの 2 種類が考えられる。前者に 対してはハード的に除去対策が打たれているが後者に関 しては何ら対策がなされておらず，かつ付着量も多いと
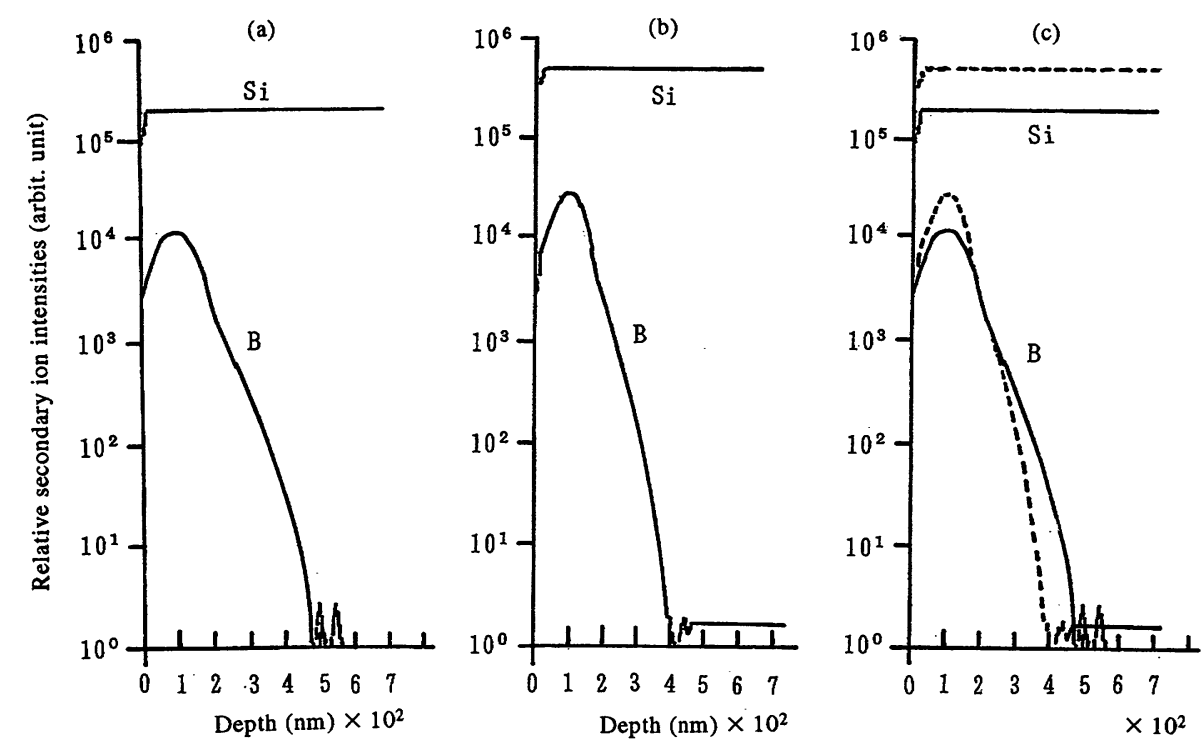

Fig. 6 Depth profiles measured by conventional technique and new mini-projection technique. (a) Conventional, (b) proposed, (c) comparison of (a) and (b).

Table 3 Comparison of standard deviation, $\Delta R_{p}$ and relative sensitivity for $\mathrm{B}$ implanted in Si sample by proposed and conventional techniques.

\begin{tabular}{lcc}
\hline & Conventional technique & Proposed technique \\
\hline Standard deviation $\Delta R_{p}(\mathrm{~nm})$ & 43.5 & 38.2 \\
\hline Ion intensity ratio for proposed and conventional technique & 1.0 & 2.4 \\
\hline
\end{tabular}


考えられるので，前者に比較してより大きな影響因子と 考えられる。 $\mathrm{B}$ の検出感度は従来技術による測定值を基 準にして示したが，本技法による感度向上は，従来技法 に対して約 2.4 倍向上していることがわかった。一方, バックグラウンドについても両者で差は少なく, $\mathrm{B}$ 濃度 分布のダイナミックレンジに関しても 2.4 倍の向上が あったといえる。この結果は, 開発したミ二突起法で は, 2 次イオン光学系に導入されるイオンはすべて真の 信号を有しており，妨害イオンはほぼ完璧に回避されて いるものと考えられる。

以上の実験結果より，ミニ突起を作製する試料前処理 と 2 次イオン検出の高アクセプタンス化を図る二つの新 技法を組合せることにより, 高感度化と深さ方向濃度分 布測定の高分解能化が同時に達成できることが明らかに なった。

\section{5. おわりに}

SIMS の深さ方向濃度分布の高精度測定を指向して, 分析領域を残して周辺をイオンエッチングにより除去 し, ミ二突起を作製する試料前処理法と 2 次イオンの有 効利用を目的とした 2 次イオン引出レンズ系の高アクセ プタンス化を組合せた新しいミニ突起法を開発した。

本技法の二つの基本技術の有効性を個々に評価する ことを目的として，まず，試料として Cおよび $\mathrm{O}$ を含 有する $\alpha \mathrm{Si}: \mathrm{H}-\mathrm{Si}$ の二層系を用い, $\alpha \mathrm{Si}: \mathrm{H}$ と Si 基板 との間の C および $\mathrm{O}$ 濃度分布の急峻性すなわち深さ方 向分解能を評価した。その結果, 感度低下を伴わずに深
さ方向分解能が約 $1 / 3$ に改善された。つぎにB 注入 $\mathrm{Si}$ 試 料の深さ方向濃度分布測定に上述の二つの基本技術を併 用したミ二突起法を適用し, 標準偏差值, $\Delta R_{p}$ の理論値 からの偏差として, 従来法の $16 \%$ に対して $2 \%$ を得た。 さらに感度に関しては, 引出レンズの高アクセプタンス 化により，2.4 倍の高感度化が達成された。

今後の課題として, ミ二突起法の微小領域分析への適 用があげられるが, 微小領域分析では, 1 次イオンビー ム分布の裾部に源をもつイオンの影響領域すなわち周辺 エッチング領域を十分に把握することが必要であろう。

\section{文 献}

1) T. Ishitani, R. Shimizu and H. Tamura : Appl. Phys. 6, 277 (1975).

2) 住谷 弘幸, 池辺 義紀, 田村一二三, 関 節子: 表 面科学 14, 500 (1993).

3) 近藤 敏郎, 田村一二三：特許第 925,396 号.

4) H. Tamura : "Secondary Ion Mass Spectrometry, SIMS IX", ed. by. A. Benninghoven, T. Nihei, R. Shimizu and H. W. Werner (John Wiley \& Sons, 1993) P. 248.

5) H. Tamura, T. Kondo, I. Kamnomata, K. Nakamura and Y. Nakamura : Jpn. J. Appl. Phys. Suppl. 2, Pt. 1, 379 (1974).

6) 日本化学会：“実験科学講座 続14 質量スペクト ル”（丸善, 1961) p. 100.

7) J. F. Gibbons, W. S. Johnson and S. W. Mylroie : Projected Range Statistics, Semiconductors and Related Materials 2nd editor, Dowden, Hutchinson and Ross, Inc. (1975). 